\title{
Reference Gene Selection for Real-time Quantitative Reverse-transcription Polymerase Chain Reaction in Flower Buds of Marigold
}

\author{
Nan Tang \\ Key Laboratory of Landscape Plants and Horticulture of Qinghai Province, Plateau Flower \\ Research Center of Qinghai University, Xining 810016, China; and State Key Laboratory of \\ Plateau Ecology and Agriculture, Qinghai University, Xining 810016, China \\ Wuhua Zhang, Liwen Chen, Yan Wang, and Daocheng Tang \\ Key Laboratory of Landscape Plants and Horticulture of Qinghai Province, Plateau Flower \\ Research Center of Qinghai University, Xining 810016, China
}

AdDitional Index words. flower development, gene expression, male sterility, normalization, qRT-PCR.

\begin{abstract}
Marigold (Tagetes erecta) is an important commercial plant because of its ornamental, industrial, and medicinal values. Male-sterile two-type lines are important for heterosis utilization and breeding of marigold. Mining of fertility-related genes may help to elucidate the mechanisms underlying male sterility. Quantitative reverse-transcription polymerase chain reaction (qRT-PCR) is a popular and useful tool for analyzing the expression level of a specific gene. Notably, identifying a suitable reference gene is important for data normalization because it affects the accuracy of quantitative analysis. However, at present, no reference genes are available for marigold. During the current study, 10 candidate reference genes were selected and their expression levels in different samples were analyzed by qRT-PCR. The expression level of each gene was analyzed across different developmental stages of male-sterile and male-fertile flower buds by four software programs (geNorm, NormFinder, BestKeeper, and RefFinder). The results showed that different reference genes are required for male-sterile and male-fertile samples, even if they belong to the same line. For male-sterile samples, the ribosomal protein S5/18S ribosomal RNA (RPS5/18S) gene pair was the best reference for qRT-PCR normalization, and glyceraldehyde-3-phosphate dehydrogenase (GAPDH) could be used as an alternative. For male-fertile samples, elongation factor 1-alpha $(E F 1 \alpha)$ and $R P S 5$ were the most suitable reference genes, and Ubiquitin-conjugating enzyme $(U B C)$ could be used as an alternative. Beta-actin $(A C T B)$, tubulin beta $(T U B)$, and phenylalanine ammonia-lyase $(P A L)$ should not be used as reference genes because they were the most unstable genes in flower buds of marigold. The results of the current study may facilitate the selection of reference genes for analyzing the expression patterns of genes involved in flower development related to male sterility in marigold.
\end{abstract}

Marigold (Tagetes erecta) is commercially cultivated worldwide because of its ornamental, industrial, and medicinal values (Ayyadurai et al., 2013). The flower is a typical capitulum that consists of ray florets and disc florets. The complexity of the capitulum structure hinders efforts to perform artificial emasculation during hybridization. Male sterility is a common phenomenon in plants and has been observed in many plant species (Ayyadurai et al., 2013; Ba et al., 2013; Dewey et al., 1991; Li et al., 2015; Pring et al., 2006; Yang et al., 2010). Male sterility appears as abnormal stamens that cannot produce pollen or aborted pollens (Gómez et al., 2015). Male-sterile plants of marigold have normal and fertile pistils but abortive stamens, thus making them convenient for pollination (Sreekala and Raghava, 2003). Male sterility provides an alternative approach for plant breeders (Ai et al., 2015; Liu et al., 2015). Compared with other cross-breeding methods, the application of male-sterile lines to produce hybrids is a cost-effective method that could improve the quality of hybrids (Fernández Gómez and Wilson, 2014;

Received for publication 19 Apr. 2021. Accepted for publication 17 June 2021.

Published online 9 August 2021

D.T. is the corresponding author. E-mail: tangdaocheng6333@163.com.

This is an open access article distributed under the CC BY-NC-ND license (https://creativecommons.org/licenses/by-nc-nd/4.0/).
Villar-Martínez et al., 2005). Male-sterile two-type lines are important for heterosis utilization and breeding of marigold. Therefore, identifying key genes related to fertility is crucial for elucidating the mechanisms underlying male sterility.

To elucidate the mechanism governing male sterility, many studies have been performed to mine fertility-related genes (Chen et al., 2012; Kim et al., 2007; Xu et al., 2014). Transcriptome profiling has been frequently used for the discovery of genes; it calculates the expression of genes based on mathematical modeling, and a certain degree of error is unavoidable. Quantification of the gene expression level is a means of validating target genes and helps to elucidate the molecular mechanisms underlying male sterility. Generally, qRT-PCR is used to validate the expression level of a specific gene. qRT-PCR is a quantification technology for nucleic acids that was developed based on qualitative PCR technology (Freeman et al., 1999). It is considered the most suitable technique for gene expression analyses and has the advantages of high specificity, high sensitivity, and good reproducibility. Analyses of gene expression using qRTPCR require stable reference genes as internal controls to normalize the data. The accuracy of the quantitative analysis is largely dependent on the selection of suitable reference genes (Bustin, 2002). Incorrect results regarding targeted gene normalization can be obtained if an improper reference gene is used 
(Gutierrez et al., 2008). Therefore, the selection of reference genes is one of the key steps when performing qRT-PCR analyses.

Ideal reference genes should be expressed stably in all cells or tissues; these genes are generally referred to as housekeeping genes (Thellin et al., 1999). However, an ideal universal reference gene does not exist because the stability of gene expression is relative. The most commonly used reference genes include $A C T B, G A P D H, E F 1 \alpha$, polyubiquitin $(U B Q)$, tubulin, and $18 S$ $r R N A$ (Bustin, 2002; Radoni et al., 2004; Tomasz et al., 2005). Studies have shown that the reference genes are expressed at different levels in different tissues (Wang, et al., 2014a), developmental stages (Martins et al., 2016), cultivars (Park et al., 2012), and experimental conditions (Zhu et al., 2012). Even with the frequently used actin and other traditional housekeeping genes, the expression level also changes with variations in experimental conditions (Die et al., 2010; $\mathrm{Hu}$ et al., 2009; Li et al., 2012). Hence, to obtain accurate and reliable qRT-PCR results, it is necessary to select suitable reference genes to normalize the data according to the sample type and experimental conditions. Many studies have been conducted to screen optimal reference genes in crops such as soybean [Glycine max (Raman et al., 2015)], potato [Solanum tuberosum (Mariot et al., 2015)], and tomato [Solanum lycopersicum (Løvdal and Lillo, 2009)]. Gu et al. (2011) found that $E F 1 \alpha$ was the best reference gene for plants under aphid-infestation stress, whereas $P P 2 A c s$ performed best under heat and waterlogging stress. $A C T B$ was generally the least stable reference gene. Fu et al. (2013) suggested that metalloprotease (MTP), SKP1/ASK-interacting protein 16 (SKIP16), and phosphoglycerate kinase $(P G K)$ were the most stable genes in different tissues during various developmental stages and with photoperiodic treatments for chrysanthemum (Chrysanthemum lavandulifolium). Furthermore, there were differences in optimal reference genes among chrysanthemum cultivars. $P G K$ performed best in potted cultivars, whereas $S A N D$ and $P G K$ were most stable in Chinese large-flower cultivars (Qi et al., 2016). However, to the best of our knowledge, no report has described the screening of reference genes for marigold.

Male-sterile two-type lines, which consist of $50 \%$ male-fertile plants and 50\% male-sterile plants, are the most commonly used male-sterile type for heterosis utilization during marigold breeding (Tang et al., 2020). In the present study, the expression levels of 10 candidate reference genes in flower buds of different fertility types during development were compared. The suitable reference genes identified during this study may enable researchers to achieve more accurate and reliable qRT-PCR normalization for gene expression studies of marigold. The results of this study may contribute significantly to the study of marigold, especially in studies of genes that are relevant to flower development and male sterility.

\section{Materials and Methods}

Plant Materials. Marigold male-sterile two-type line 2-2 was provided by the Plateau Flower Center of Qinghai University, Xining, China (lat. $36^{\circ} 43^{\prime} 27^{\prime \prime} \mathrm{N}$, long. $101^{\circ} 44^{\prime} 42^{\prime \prime} \mathrm{E}$ ). The male-sterile line of $2-2$ is recessive homozygous, whereas its male-fertile line is heterozygous. Therefore, the crossing of a sterile line and fertile line always produces $50 \%$ sterile plants and $50 \%$ fertile plants. Seeds were germinated using nursery medium (Floragard Vertriebs, Oldenburg, Germany) and transferred to pots when the plant heights reached $\approx 10 \mathrm{~cm}$. The plants were kept at $23 \pm 1{ }^{\circ} \mathrm{C}$, with a daylength of $16 \mathrm{~h}$. The relative humidity was maintained between $50 \%$ and $70 \%$. Male-sterile and malefertile plants were divided according to the flower phenotype (Tang et al., 2020). The development of flower buds was divided into five stages by diameter $(0.3,0.5,0.8,1$, and $1.2 \mathrm{~cm})$. Flower buds of each stage were collected for both male-sterile and malefertile plants. Three biological replicates were collected for the flower bud of each stage. Samples were frozen in liquid nitrogen immediately and kept at $-80^{\circ} \mathrm{C}$.

EXtRaction OF TOTAL RNA AND SYNTHESIS OF THE FIRST CDNA. Total RNA of all samples was extracted from flower buds of fertile and sterile plants of different sizes using TRNzol Universal Reagent (DP424; TianGen Biotech, Beijing, China). Extracted RNA was checked by $1 \%(\mathrm{w} / \mathrm{v})$ agarose gel electrophoresis, and the concentration of RNA samples was measured using a TGem spectrophotometer (OSE-260, TianGen Biotech). The RNA concentration was adjusted to $100 \mathrm{ng} \cdot \mu \mathrm{L}^{-1}$. Firststrand cDNA was synthesized using the PrimeScript ${ }^{\mathrm{TM}}$ II firststrand cDNA synthesis kit (6210A; Takara Biomedical Technology, Beijing, China). According to the manufacturer's protocol, cDNA was diluted 10-fold before analysis using real-time PCR.

REFERENCE GENE SELECTION AND PRIMER DESIGN. A total of 10 genes (Table 1) were selected as candidates to determine the most suitable reference gene of marigold. Sequences of these genes were obtained from transcriptome data of a previous study (Tang et al., 2020). Primers were designed using Primer Premier 5 software (PREMIER Biosoft International, Palo Alto, CA) based on the following criteria: the length of the primer ranged from 18 to $25 \mathrm{bp}$, the guanine/cytosine content ranged from $45 \%$ to $55 \%$, the target fragment size was 100 to $250 \mathrm{bp}$, and the difference in the temperature between the forward primer and reverse primer was less than $1{ }^{\circ} \mathrm{C}$. Information regarding the primers is presented in Table 1. The performance of primers was tested by PCR, and the amplification results were verified by $2 \%$ (w/v) agarose gel electrophoresis.

QRT-PCR ANALYSIS. The reaction system contained $10 \mu \mathrm{L}$ of $2 \times$ SuperReal Color PreMix (TianGen Biotech), $1 \mu \mathrm{L}$ of template (100 ng), $0.5 \mu \mathrm{L}$ of each amplification primer $(10 \mu \mathrm{M})$, and double-distilled water to a final volume of $20 \mu \mathrm{L}$. Reactions were performed under the following conditions: $95^{\circ} \mathrm{C}$ for $5 \mathrm{~min}$ followed by 40 cycles of $95^{\circ} \mathrm{C}$ for $10 \mathrm{~s}, 55^{\circ} \mathrm{C}$ for $20 \mathrm{~s}$, and $72^{\circ} \mathrm{C}$ for $30 \mathrm{~s}$. Three technical repeats were performed. Melting curves were recorded by heating from 65 to $95^{\circ} \mathrm{C}$ to determine the specificity of the reactions. Real-time PCR, fluorescence data collection, and data analysis were performed using a PCR platform (LightCycler 480; Roche, Basel, Switzerland). The cycle threshold $(\mathrm{Ct})$ value of each reaction was automatically calculated by LightCycler $480 \mathrm{SW}$ version 1.5 software (Roche). A standard curve was drawn using amplification products for each pair of primers. The amplification efficiency (E) of each primer pair was calculated from the slope of the standard curve using the equation $\mathrm{E}(\%)=\left(10^{-1 / \text { slope }}-1\right) \times 100 \%$ (Pfaffl et al., 2004).

StabiLITy OF CANDIDATE REFERENCE GENES EXPRESSION. The expression of candidate reference genes was determined by qRT-PCR, and the raw Ct values were processed and analyzed using the publicly available software tools geNorm V3.5 (Vandesompele et al., 2002), NormFinder (Andersen et al., 2004), and BestKeeper (Pfaffl et al., 2004). The geNorm program calculates the gene expression stability value $(\mathrm{M})$ based on the 
Table 1. Ten candidate reference genes in marigold and parameters obtained via real-time polymerase chain reaction.

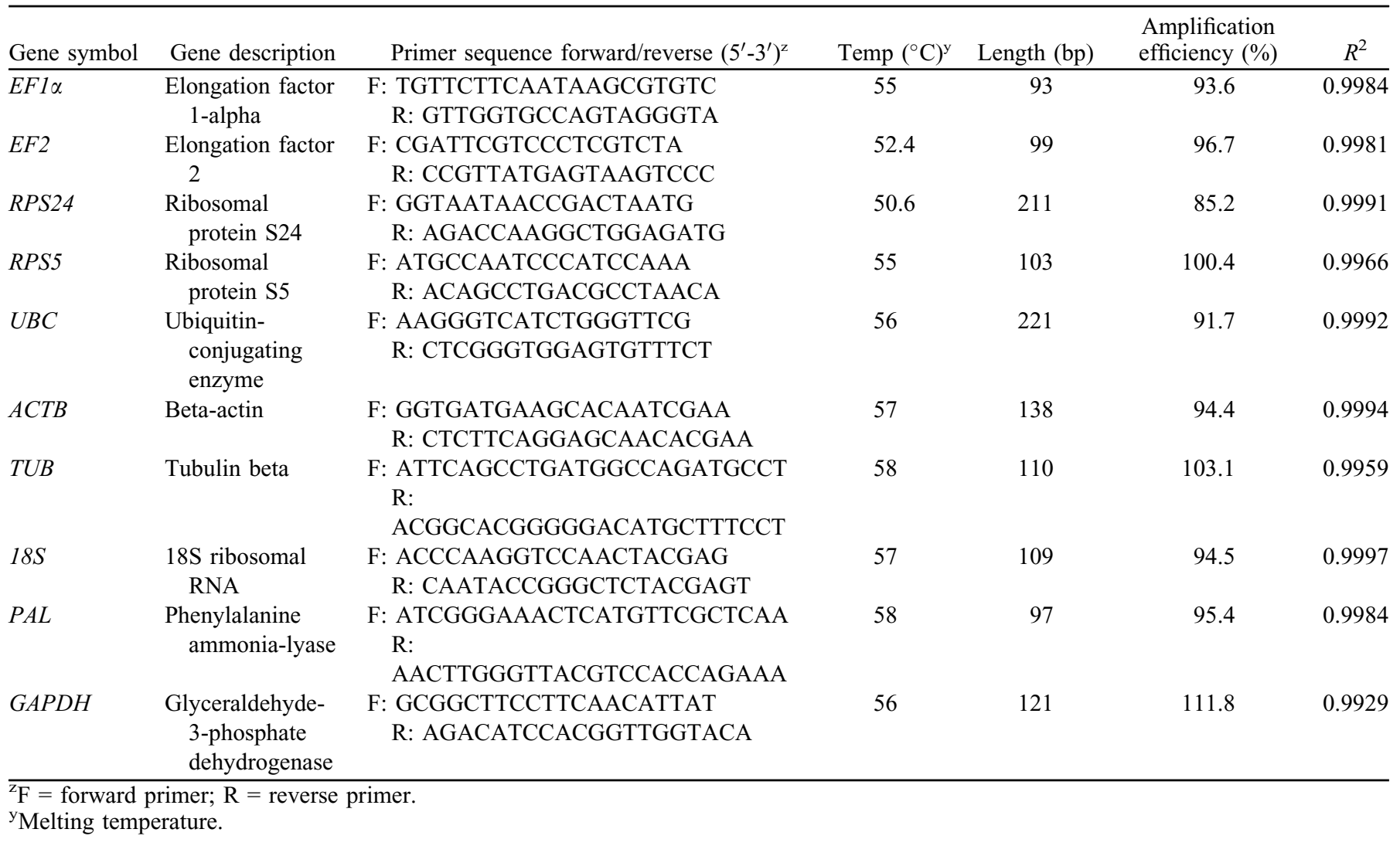

average pairwise variation (V) between different candidate genes. Lower $\mathrm{M}$ values represent better stability. The optimal number of reference genes for accurate representation of gene expression is based on the calculation of pairwise variation analysis $\left(\mathrm{V}_{\mathrm{n}} / \mathrm{V}_{\mathrm{n}+1}\right)$ between the normalization factors NFn and NFn $+1)$. The optimal number of reference genes is $n$ when the value $\mathrm{V}_{\mathrm{n}} / \mathrm{V}_{\mathrm{n}+1}$ is less than 0.15 (Vandesompele et al., 2002). The optimal number of reference genes is $n+1$ if the value $V_{n}$ / $\mathrm{V}_{\mathrm{n}+1}$ is higher than 0.15 . NormFinder calculates the intragroup and intergroup variations using an analysis of variance-based mathematical model, and the gene expression stability of the reference genes is ranked. With BestKeeper, the average $\mathrm{Ct}$ value is used to analyze the stability value of candidate genes. The correlation coefficient $(r)$, coefficient of variation $(\mathrm{CV})$, and SD are used as parameters to determine the stability of candidate genes. Lower $\mathrm{CV} \pm \mathrm{SD}$ values and higher R values indicate that the reference gene has higher stability (Maroufi et al., 2010). To validate the results of geNorm, NormFinder, and BestKeeper, a comprehensive ranking was obtained using RefFinder (Xie et al., 2012) to identify the most reliable gene.

\section{Results}

Selection Of CANDIDATE REFERENCE GENES. A total of 10 candidate reference genes (EF1 $\alpha, E F 2, R P S 24, R P S 5, U B C, A C T B$, $T U B, 18 S, P A L$, and $G A P D H)$ were selected according to previous studies and transcriptome data of marigold. The specificity of primers was determined by agarose gel electrophoresis and a melting curve analysis (Supplemental Figs. 1 and 2). The presence of a single peak in the melting curve confirmed the specificity of amplicons. The PCR amplification efficiencies for the 10 genes varied from $85.2 \%$ (RPS24) to $111.8 \%(G A P D H)$ (Table 1). The correlation coefficient $\left(r^{2}\right)$ ranged from 0.9966 (RPS5) to 0.9997 (18S).

EXPRESSION PROFILES OF CANDIDATE REFERENCE GENES. The expression levels of the 10 candidate reference genes are shown in Fig. 1. The mean $\mathrm{Ct}$ values for the reference genes ranged from $6.96(18 S)$ to $30.32(P A L)$, indicating remarkable variation. Lower $\mathrm{Ct}$ values indicate higher expression levels. Therefore, $18 S$ presented the highest expression level in all samples because it exhibited the smallest $\mathrm{Ct}$ value $(9.12 \pm 1.89)$. PAL showed the lowest expression level because it presented the largest $\mathrm{Ct}$ value (30.32 \pm 0.64$)$. Among the 10 candidate genes, TUB showed high variability among different samples because it showed the largest SD value. Although the $\mathrm{Ct}$ value can be used as a parameter to evaluate the expression level and the SD can reflect the stability of the genes, more accurate and systematic analyses are required to evaluate the reliability of the candidate reference genes under specific conditions.

StabiLity OF REFERENCE GENES. The stability of the 10 candidate reference genes among flower developmental stages was evaluated for male-sterile and male-fertile plants separately. The data were analyzed in three sets. Set 1 and set 2 were composed of male-sterile and male-fertile samples, respectively. Set 3 consisted of all samples to analyze the overall stability. Four software programs (geNorm, NormFinder, BestKeeper, and RefFinder) were used to evaluate the 10 candidate reference genes.

The geNorm program calculates $M$ values (Supplemental Table 1) to represent the stability of the reference genes. The 


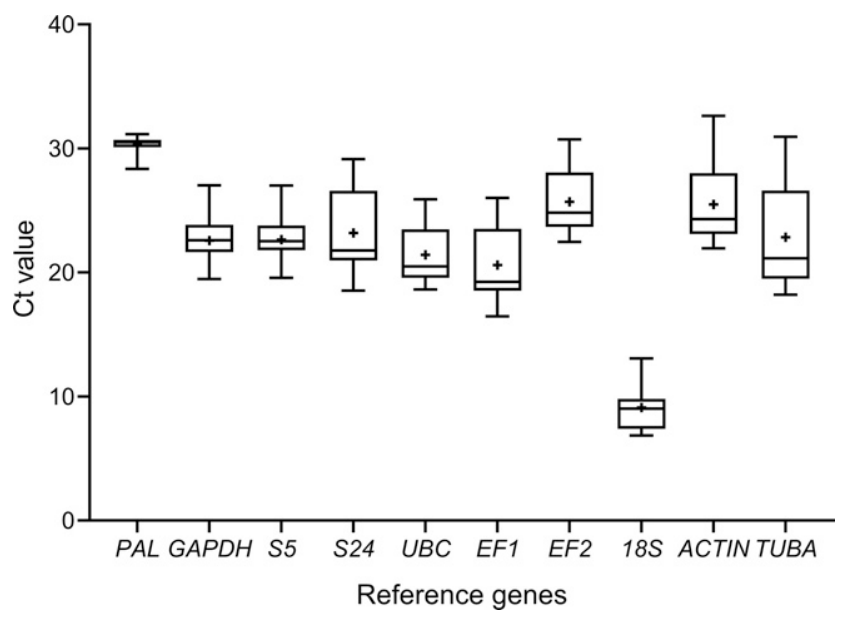

Fig. 1. Expression profiles of 10 candidate reference genes in flower buds of marigold across all samples throughout the developmental stages based on the raw cycle threshold $(\mathrm{Ct})$ values. The boxes show two interquartile values. The line within the box shows the median and mean. The whiskers represent the $95 \%$ confidence interval.

genes with the lowest $\mathrm{M}$ values have the most stable expression. The 10 reference genes were ranked according to the $M$ values (Fig. 2). The $\mathrm{M}$ values of stably expressed reference genes were less than 1.5. Therefore, $P A L$ is not a good reference gene because its $M$ value was higher than 1.5 in set 2 and set 3 . In male-sterile plants (set 1), ACTB was the least stable reference gene among the various developmental stages. According to the analysis, GAPDH and RPS5 were the most stable reference genes because they exhibited the lowest $M$ values in different sample sets. The reference genes showed different stability in male-fertile and male-sterile plants. For male-sterile samples, RPS24 was the third most stable reference gene, followed by GAPDH and RPS5. However, in the set of male-fertile samples, the third most stable reference gene was $18 S$.

Pairwise variation was calculated to estimate the ideal number of reference genes. When $\mathrm{Vn} / \mathrm{Vn}+1<0.15$, the optimum number of reference genes is $\mathrm{n}$. If $\mathrm{Vn} / \mathrm{Vn}+1>0.15$, then the optimum number of reference genes is $n+1$. For set 1 and set 2 , two reference genes were sufficient for reliable normalization because the V2/V3 values were less than 0.15 (Fig. 3). Hence, the combination of GAPDH and RPS5 was the best selection of reference genes based on the geNorm analysis. However, it failed to obtain the optimal number of reference genes for all samples (set 3). It was observed that all of the pairwise variation values exceeded 0.15 , indicating that the quantification might not be accurately normalized, even if all candidate reference genes were used in the qRT-PCR. This result showed that the expression of the candidate genes differed in male-sterile and male-fertile samples.

The candidate reference genes were ranked according to their stability values calculated by NormFinder (Table 2). UBC was the most stable reference gene in set 2 (male-fertile) and set 3 (total). In set 1 (male-sterile), although $18 S(0.408)$ showed the lowest stability value, RPS5 (0.465) and $U B C(0.481)$ were also determined to be reliable reference genes. In accordance with the results of geNorm analysis, $P A L$ and $A C T B$ showed the lowest stability among the 10 candidate genes.

The best-suited reference gene was further determined by BestKeeper using a pairwise correlation analysis of the raw $\mathrm{Ct}$ values. The stability of reference genes was assessed according to $\mathrm{r}, \mathrm{CV}$, and SD. The greater the correlation coefficient that was presented, the higher the stability of the gene. Reference genes were considered more stable if they had lower SD values. In general, genes are considered unstable if the SD values are larger than 1.0. In set 1 , all 10 candidate reference genes had SD values less than 1.0 (Table 3). Furthermore, 18S, RPS24, GAPDH, and $R P S 5$ exhibited significantly high correlations with each candidate gene. Moreover, $18 S$ was determined to be the most stable reference gene because it had the highest $\mathrm{r}$ value (0.843). Although $P A L$ and $U B C$ had low sD values, they were excluded because of their low correlation coefficient. In set 2 and set 3 , most of the genes were considered inconsistent by BestKeeper because of high variation $(\mathrm{SD}>1)$. However, these candidate genes (except $P A L$ ) were well-correlated; therefore, they should be retained for further analysis.

Finally, a comprehensive ranking of the candidate reference genes was obtained using RefFinder (Table 4). Different ranking results were obtained among different algorithms, and discrepancies were observed when an analysis using a single method was compared with the use of an integrated analysis. However, the most stable genes exhibited similarities. In set $1, R P S 5,18 S$, and $G A P D H$ were the three most stable reference genes (Fig. 4). RPS5 was determined to be the most recommended gene to normalize the qRT-PCR results for male-sterile marigold, followed by $18 S$ and $G A P D H$. In set $2, E F 1 \alpha, R P S 5$, and $U B C$ were observed to be the most stable. If male-fertile and male-sterile plants were analyzed together, then the three most stable genes were $U B C, 18 S$, and $G A P D H$. The least stable reference genes were determined to be $T U B, A C T B$, and RPS24.

\section{Discussion}

Screening one or more stable reference genes is very important for target gene normalization and quantitative analysis using qRT-PCR. Although marigold is cultivated worldwide as a landscape plant, and although its flowers are used for xanthophyll extraction, at present, no reliable reference genes have been identified for this species. To screen for suitable reference genes for normalization in flower buds of marigold, 10 candidate reference genes were chosen based on previous research. The expression stability of these genes was analyzed using geNorm, NormFinder, and BestKeeper. Based on the results of this study, the reference genes presented different stability in male-sterile and male-fertile plants of marigold. Therefore, different reference genes should be selected for qRT-PCR analysis for different plant types to obtain accurate results.

Analyses using geNorm, NormFinder, and BestKeeper showed differences in the ranking of stable genes, but the ranking was more consistent for excluding the least stable genes. For example, using male-sterile samples, the geNorm analysis suggested that GAPDH and RPS5 were the optimal reference genes. However, $18 S$ and RPS5 were ranked first and second according to the NormFinder results. BestKeeper yielded distinctly different results compared to those of geNorm and NormFinder: $U B C$ and $P A L$ were ranked the first and second suggested reference genes, respectively. All three software programs indicated that $A C T B$ was the least stable reference gene in male-sterile samples. Similar ranking results were also found during different fruit ripening stages for apple [Malus $\times$ domestica (Perini et al., 2014)], tissues and organs of citrus [Citrus sp. (Mafra et al., 

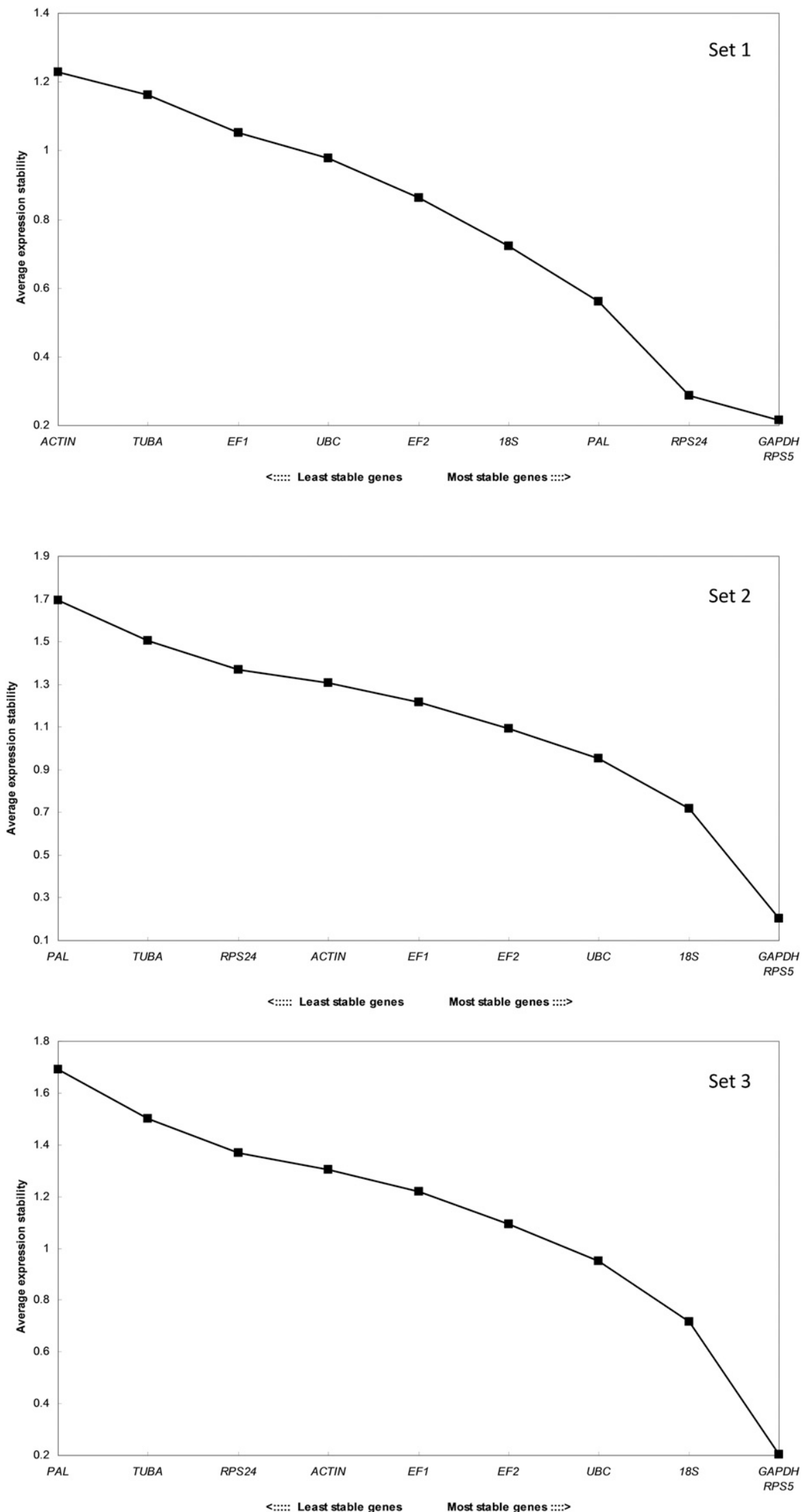

Fig. 2. The average expression stability of candidate reference genes in flower buds of marigold was evaluated by the geNorm program (Vandesompele et al., 2002). It calculates an average expression stability values (M) based on the average pairwise variation existing between all pairs of the candidate genes for male-sterile samples (set 1), male-fertile samples (set 2), and all samples (set 3). A lower M value represents more stable expression. 


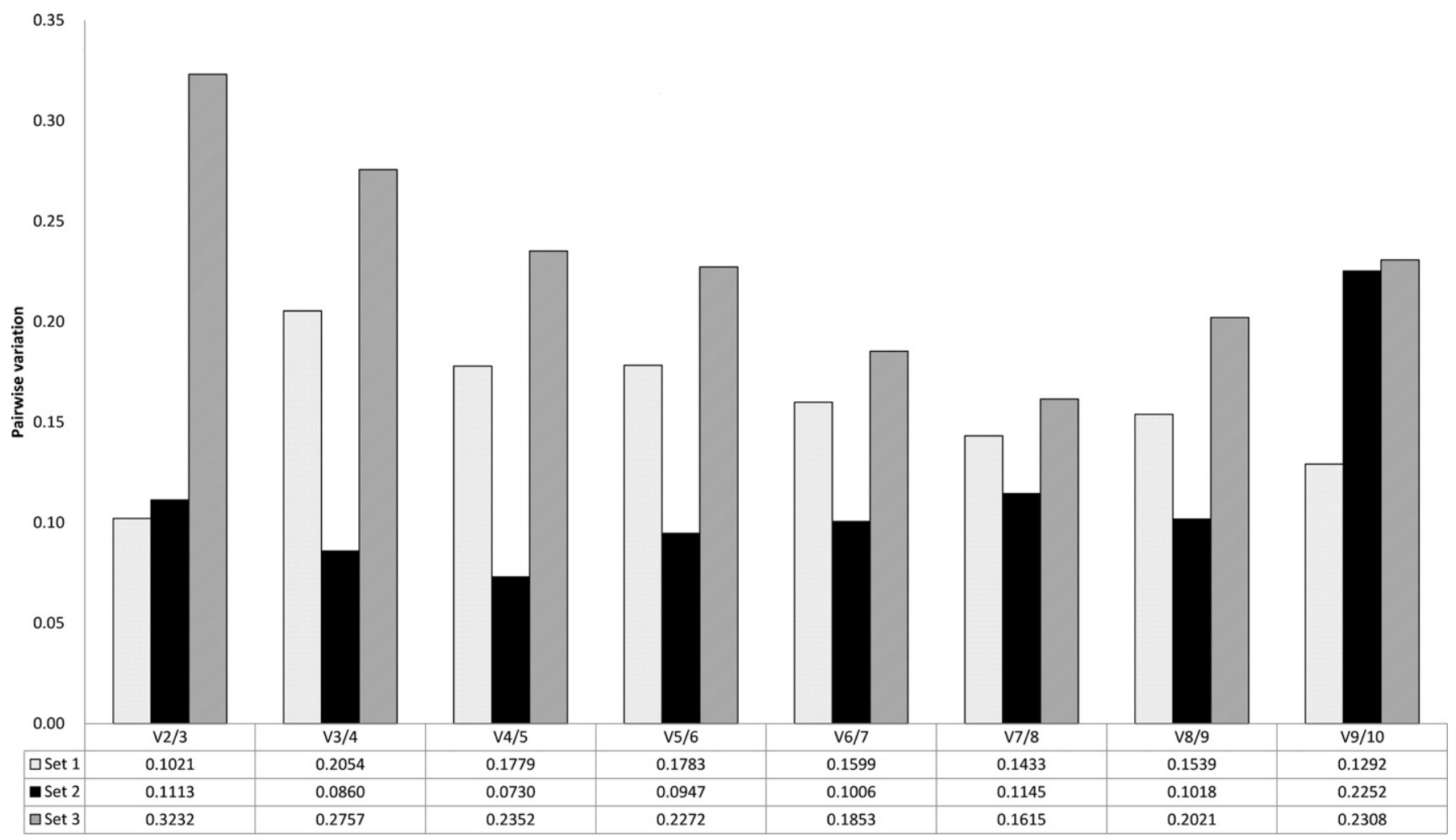

Fig. 3. Pairwise variation values (V) of candidate reference genes in flower buds of marigold calculated by geNorm (Vandesompele et al., 2002). Pairwise variation $(\mathrm{Vn} / \mathrm{Vn}+1)$ was analyzed between the normalization factors NFn and NFn+1, where $\mathrm{n}$ is the number of genes involved in the normalization factor. When $\mathrm{Vn} / \mathrm{Vn}+1<0.15$, the optimal number of reference genes is $\mathrm{n}$.

2012)], and during different flower and fruit development stages for cotton [Gossypium hirsutum (Artico et al., 2010)]. These discrepancies were primarily attributable to the different algorithms used by the different software tools. geNorm has been noted as one of the best tools for determining the most stable reference genes for qRT-PCR, and it has been used in many similar studies (Expósito-Rodríguez et al., 2008; Jain et al., 2006; Jian et al., 2008; Maroufi et al., 2010). Because NormFinder estimates both intergroup and intragroup variations to calculate the stability value, it was presumed that this software provides more precise results among subsets composed of different sample types (Martins et al., 2016). Paolacci et al. (2009) found that NormFinder

Table 2. Ranking of the expression stability (M) of 10 candidate reference genes in flower buds of marigold according to NormFinder (Andersen et al., 2004).

\begin{tabular}{|c|c|c|c|c|c|c|}
\hline \multirow[b]{2}{*}{ Ranking $^{z}$} & \multicolumn{2}{|c|}{ Male-sterile } & \multicolumn{2}{|c|}{ Male-fertile } & \multicolumn{2}{|c|}{ Total } \\
\hline & Gene & M & Gene & M & Gene & M \\
\hline 1 & $18 S$ & 0.408 & $U B C$ & 0.021 & $U B C$ & 0.249 \\
\hline 2 & RPS5 & 0.465 & $E F 1 \alpha$ & 0.080 & $18 S$ & 0.522 \\
\hline 3 & $U B C$ & 0.481 & RPS5 & 0.127 & $E F 2$ & 0.553 \\
\hline 4 & $G A P D H$ & 0.531 & $G A P D H$ & 0.190 & $E F 1 \alpha$ & 0.700 \\
\hline 5 & $P A L$ & 0.556 & RPS24 & 0.200 & $G A P D H$ & 0.738 \\
\hline 6 & $R P S 24$ & 0.573 & $E F 2$ & 0.302 & RPS5 & 0.771 \\
\hline 7 & $E F 1 \alpha$ & 0.705 & $18 S$ & 0.394 & $A C T B$ & 0.783 \\
\hline 8 & $E F 2$ & 0.742 & $A C T B$ & 0.661 & RPS24 & 0.814 \\
\hline 9 & $T U B$ & 0.849 & $T U B$ & 0.770 & $T U B$ & 1.376 \\
\hline 10 & $A C T B$ & 0.872 & $P A L$ & 1.556 & $P A L$ & 1.579 \\
\hline
\end{tabular}

$\overline{\mathrm{z}} 1=$ most stable gene; $10=$ least stable gene. was more effective than geNorm for wheat (Triticum aestivum). BestKeeper determines the most stable reference genes by using repeated pairwise correlations, and it always shows diverse results compared with those of geNorm and NormFinder (Piehler et al., 2010). There is no consensus regarding which type of algorithm should be used to determine the stability of gene expression; hence, comprehensive analyses using different software programs are necessary to achieve the best results (Francis et al., 2013; Qi et al., 2016; Xiang et al., 2018). To avoid errors caused by analysis using a single software tool, a geometric mean algorithm was used to rank the reference genes comprehensively. This ranking reflected the stability trend of the reference gene to some extent (dos Santos et al., 2019; Lin et al., 2019).

Researchers have proposed that using only one reference gene for qRT-PCR is not sufficient to obtain reliable results (Pabinger et al., 2009; Vandesompele et al., 2002). geNorm provides the optimal number of reference genes that should be included in the normalization of qRT-PCR, whereas NormFinder only estimates the best single gene. During this study of flower buds of both male-sterile and male-fertile plants, two reference genes were sufficient for reliable qRT-PCR normalization. However, if the male-sterile and male-fertile samples were pooled together, then all pairwise variation values exceeded the threshold of 0.15 . This finding signified that the quantification might not be accurately normalized, even if all candidate reference genes are used, and that different reference genes should be used for male-sterile and male-fertile samples of marigold when performing a qRT-PCR analysis of target genes. This result 
Table 3. Expression stability of 10 candidate reference genes in flower buds of marigold calculated by BestKeeper (Pfaffl et al., 2004).

\begin{tabular}{|c|c|c|c|c|c|c|c|c|c|c|c|}
\hline \multicolumn{4}{|c|}{ Male-sterile } & \multicolumn{4}{|c|}{ Male-fertile } & \multicolumn{4}{|c|}{ Total } \\
\hline Gene & $\mathrm{CV}^{\mathrm{z}}$ & $\mathrm{SD}^{\mathrm{y}}$ & $r^{\mathrm{x}}$ & Gene & $\mathrm{CV}$ & SD & $r$ & Gene & $\mathrm{CV}$ & SD & $r$ \\
\hline $18 S$ & 10.25 & 0.82 & $0.843^{*}$ & $E F 1 \alpha$ & 7.18 & 1.65 & 0.998 & $U B C$ & 8.93 & 1.91 & 0.972 \\
\hline GAPDH & 3.90 & 0.85 & $0.722 *$ & RPS5 & 7.96 & 1.86 & 0.994 & RPS24 & 12.10 & 2.81 & 0.966 \\
\hline RPS5 & 3.33 & 0.73 & $0.664 *$ & $G A P D H$ & 8.09 & 1.89 & 0.994 & $18 S$ & 16.29 & 1.49 & 0.955 \\
\hline$T U B$ & 4.81 & 0.95 & 0.533 & $U B C$ & 6.82 & 1.57 & 0.990 & $E F 2$ & 8.81 & 2.26 & 0.955 \\
\hline$P A L$ & 1.97 & 0.59 & 0.444 & $A C T B$ & 8.22 & 2.26 & 0.978 & $G A P D H$ & 6.32 & 1.43 & 0.891 \\
\hline$U B C$ & 2.87 & 0.57 & 0.436 & $18 S$ & 15.86 & 1.62 & 0.972 & RPS5 & 6.05 & 1.37 & 0.882 \\
\hline$E F 1 \alpha$ & 3.44 & 0.63 & 0.220 & $P A L$ & 0.70 & 0.21 & 0.599 & $P A L$ & 1.46 & 0.44 & 0.436 \\
\hline
\end{tabular}

${ }^{\mathrm{z}}$ Coefficient of variance expressed as a percentage of the crossing point level.

${ }^{y_{S D}}$ of the crossing point.

${ }^{x}$ Pearson correlation coefficient.

highlighted the fact that it is better to select different reference genes for different biological samples.

For male-sterile plants of marigold, geNorm suggested GAPDH/RPS5 as the most suitable pair of genes to normalize samples during different developmental stages. Furthermore, $18 S$ showed the lowest $\mathrm{M}$ value according to NormFinder, followed by RPS5. However, BestKeeper determined $18 S$ to be the most stable gene, followed by RPS24, GAPDH, and RPS5. The comprehensive analysis ranked RPS5 first, followed by $18 S$ and $G A P D H$. Ultimately, it was considered that RPS5/18S is the best gene pair that can be used for qRT-PCR normalization for different flower developmental stages of male-sterile marigold. In addition, RPS5/GAPDH could be used as an alternative. The RPS5 gene encodes a ribosomal protein that forms a part of a small subunit and is ubiquitously expressed in all cell types (Kirthi et al., 2006). At present, the application of ribosomal protein genes as housekeeping genes is controversial. Thorrez et al. (2008) provided statistical and biological evidence that ribosomal protein genes exhibit important tissue-dependent variations in mRNA expression; therefore, they believed that these genes cannot be considered true reference genes. In contrast, the family of ribosomal protein genes has been used as housekeeping genes during research of various organisms (Maria et al., 2017; Nicot et al., 2005; Yan et al., 2017; Zhou et al., 2010). These applications may have been used because the family of ribosomal protein genes includes a large number of genes, among which some are stably expressed and some are

Table 4. Recommended comprehensive ranking of 10 reference genes in flower buds of marigold by RefFinder (Xie et al., 2012).

\begin{tabular}{|c|c|c|c|}
\hline Comprehensive ranking ${ }^{\mathrm{z}}$ & Set 1 & Set 2 & Set 3 \\
\hline 1 & RPS5 & $E F 1 \alpha$ & $U B C$ \\
\hline 2 & $18 S$ & RPS5 & $18 S$ \\
\hline 3 & $G A P D H$ & $U B C$ & $G A P D H$ \\
\hline 4 & $U B C$ & $G A P D H$ & RPS5 \\
\hline 5 & $P A L$ & $R P S 24$ & $E F 2$ \\
\hline 6 & RPS24 & $P A L$ & $E F 1 \alpha$ \\
\hline 7 & $E F 1 \alpha$ & $18 S$ & $P A L$ \\
\hline 8 & $E F 2$ & $E F 2$ & $A C T B$ \\
\hline 9 & $T U B$ & $A C T B$ & RPS24 \\
\hline 10 & $A C T B$ & $T U B$ & $T U B$ \\
\hline
\end{tabular}

differentially expressed, depending on the tissue type or experimental conditions. Furthermore, $18 S$ ribosomal RNA is a housekeeping gene that is commonly used as an internal control gene in qRT-PCR. This gene was found to be the best reference gene for different developmental stages of Lentinula edodes (Xiang et al., 2018; Xu et al., 2011), wheat infected with rust (Puccinia triticina, $P$. striiformis, and $P$. graminis f.sp. tritici) (Scholtz and Visser, 2013), and developing chinese azalea (Rhododendron molle) flowers (Xiao et al., 2016). However, $18 S$ was considered the least stable reference gene for expression studies of Eucalyptus globulus adventitious rooting (de Almeida et al., 2010), jute (Corchorus capsularis) under different environmental stresses (Islam et al., 2014), and melon (Cucumis melo) infected by Fusarium (Sestili et al., 2014). However, GAPDH is a well-studied glycolytic enzyme that has a key role in energy metabolism (Bustin, 2002). Previous studies found that GAPDH cannot be used as a universal reference gene across different experimental conditions (Bustin, 2002; Goidin et al., 2001). However, the expression of GAPDH appeared stable during this study. Similarly stable expression was found in Corydalis yanhusuo under different treatment conditions (Bao et al., 2020).

For the male-fertile samples, geNorm suggested that $G A P D H / R P S 5$ is the best gene pair for normalization. However, $U B C / E F 1 \alpha$ and $E F 1 \alpha / T U B$ were suggested to be the best gene pairs by NormFinder and BestKeeper, respectively. RPS5 and GAPDH were ranked third and fourth by NormFinder and BestKeeper, respectively. Considering the results of different algorithms and the comprehensive analysis, it is suggested that the EF1 $\alpha /$ RPS5 gene pair is the reference gene for male-fertile plants of marigold. $E F 1 \alpha$ is a gene that can catalyze the binding of aminoacyl-tRNA to the A-site of the ribosome using a GTPdependent mechanism (Browning, 1996). Luo et al. (2014) found that the $E F 1 \alpha$ gene exhibited the most stable expression patterns in lily (Lilium brownii) leaves. Berumen-Varela et al. (2020) found that $E F 1 \alpha$ is the most stable reference gene in soursop (Annona muricata) fruit under cold treatment. For Rhododendron micranthum, EFl $\alpha$ and $18 S$ were selected as the most stable reference genes during leaf development (Yi et al., 2004). Furthermore, this gene has been found to be one of the most reliable reference genes in tobacco [Nicotiana tabacum (Schmidt and Delaney, 2010)], apple (Zhu et al., 2019), and several plant species. 

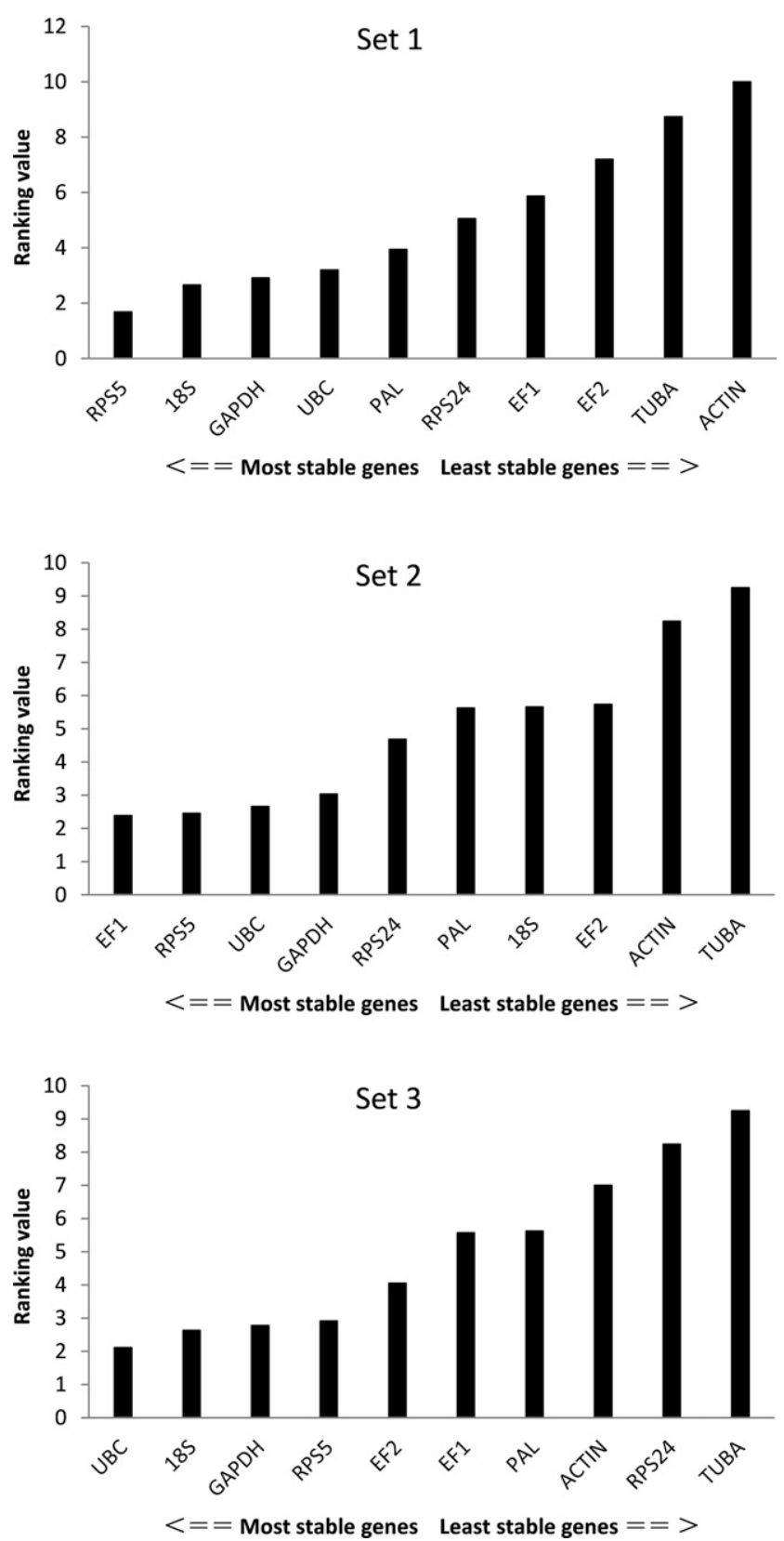

Fig. 4. Order of stability of candidate genes in flower buds of marigold according to RefFinder (Xie et al., 2012). Set 1 consists of male-sterile samples, set 2 consists of male-fertile samples, and set 3 consists of all samples.

According to the results of this study, it is not advised to use the traditional housekeeping genes $A C T B$ and $T U B$ as reference genes in marigold. $A C T B$ is one of the most widely used reference genes (Tian et al., 2015; Wang. et al., 2014b). However, it was the most variable reference gene in male-sterile flower buds during this study. The poor performance of $A C T B$ was also observed in chrysanthemum plants under biotic and abiotic stresses ( $\mathrm{Gu}$ et al., 2011), in Setaria viridis (Martins et al., 2016), and in peach [Prunus persica (Tong et al., 2009)]. It was hypothesized that every organism possesses three to four highly homologous $A C T B$ isoforms, and the relative expression amount of each isoform may vary across organs, developmental stages, and experimental conditions (Sturzenbaum and Kille, 2001). A similar conclusion has been proposed for $T U B$, which displayed highly variable expression patterns. Similarly, $T U B$ was the least stable reference gene in various peach tissue samples (Tong et al., 2009) and in the leaves and roots of Prun us spp. rootstocks under flooding conditions (Klumb et al., 2019).

\section{Conclusions}

During this study, 10 candidate reference genes were selected and evaluated for their expression stability across male-sterile and male-fertile marigold samples during the process of flower bud development. The candidate reference genes showed different expression stability in male-sterile and male-fertile samples, and different algorithms yielded different results. According to the pairwise analysis performed using geNorm, the use of two reference genes is optimal for both male-sterile and male-fertile samples. When using all samples, quantification might not be accurately normalized even if all 10 candidate reference genes are used because no pairwise variation value was below the threshold of 0.15 . For the male-sterile two-type line of marigold, even if the male-sterile and male-fertile plants are in the same line, different reference genes should be adopted for male-sterile and male-fertile plants. In conclusion, the RPS5/18S gene pair was determined to be the best reference selection for qRT-PCR of male-sterile samples in the flower buds of marigold, and $R P S 5 / G A P D H$ could be used as an alternative. Furthermore, $E F 1 \alpha / R P S 5$ was the most suitable reference gene pair for fertile male samples. $U B C$ could be the alternative. The results of this study indicate that $A C T B, T U B$, and $P A L$ should not be used for qRT-PCR normalization in marigold because they were the most unstable genes.

\section{Literature Cited}

Ai, Y., Q.H. Zhang, C. Pan, H.Y. Zhang, S. Ma, Y.H. He, and M.Z. Bao. 2015. A study of heterosis, combining ability and heritability between two male sterile lines and ten inbred lines of Tagetes patula. Euphytica 203:349-366, doi: 10.1007/s10681-014-1278-y.

Andersen, C.L., J.L. Jensen, and T.F. Ørntoft. 2004. Normalization of real-time quantitative reverse transcription-PCR data: A model-based variance estimation approach to identify genes suited for normalization, applied to bladder and colon cancer data sets. Cancer Res. 64:5245-5250, doi: 10.1158/0008-5472.can-04-0496.

Artico, S., S.M. Nardeli, O. Brilhante, M.F. Grossi-de-Sa, and M. Alves-Ferreira. 2010. Identification and evaluation of new reference genes in Gossypium hirsutum for accurate normalization of real-time quantitative RT-PCR data. BMC Plant Biol. 10:49, doi: 10.1186/ 1471-2229-10-49.

Ayyadurai, N., N. Valarmathy, S. Kannan, D. Jansirani, and A. Alsenaidy. 2013. Evaluation of cytotoxic properties of Curcuma longa and Tagetes erecta on cancer cell line (Hep2). Afr. J. Pharm. Pharmacol. 7:736-739, doi: 10.5897/AJPP12.031.

Ba, Q.S., G.S. Zhang, J.S. Wang, H.X. Che, H.Z. Liu, N. Niu, S.C. $\mathrm{Ma}$, and J.W. Wang. 2013. Relationship between metabolism of reactive oxygen species and chemically induced male sterility in wheat (Triticum aestivum L.). Can. J. Plant Sci. 93:675-681, doi: 10.4141/CJPS2012-280.

Bao, Z., K. Zhang, H. Lin, C. Li, X. Zhao, J. Wu, and S. Nian. 2020. Identification and selection of reference genes for quantitative transcript analysis in Corydalis yanhusuo. Genes (Basel) 11:130, doi: 10.3390/genes11020130.

Berumen-Varela, G., Y.A. Palomino-Hermosillo, P.U. Bautista-Rosales, G.R. Peña-Sandoval, G.G. López-Gúzman, and R. Balois-Morales. 2020. Identification of reference genes for quantitative real-time PCR in different developmental stages and under refrigeration conditions 
in soursop fruits (Annona muricata L.). Scientia Hort. 260:108893, doi: 10.1016/j.scienta.2019.108893.

Browning, K.S. 1996. The plant translational apparatus. Plant Mol. Biol. 32:107-144, doi: 10.1007/BF00039380.

Bustin, S. 2002. Quantification of mRNA using real-time reverse transcription PCR (RT-PCR): Trends and problems. J. Mol. Endocrinol. 29:23-39, doi: 10.1677/jme.0.0290023.

Chen, C.M., X.F. Hao, G.J. Chen, B.H. Cao, Q.H. Chen, S.Q. Liu, and J.J. Lei. 2012. Characterization of a new male sterility-related gene Camf1 in Capsicum annum L. Mol. Biol. Rep. 39:737-744, doi: 10.1007/s11033-011-0793-3.

de Almeida, M.R., C.M. Ruedell, F.K. Ricachenevsky, R.A. Sperotto, G. Pasquali, and A.G. Fett-Neto. 2010. Reference gene selection for quantitative reverse transcription-polymerase chain reaction normalization during in vitro adventitious rooting in Eucalyptus globulus Labill. BMC Mol. Biol. 11:1-12, doi: 10.1186/1471-2199-11-73.

Dewey, R.E., D.H. Timothy, and C.S.I. Levings. 1991. Chimeric mitochondrial genes expressed in the $\mathrm{C}$ male-sterile cytoplasm of maize. Curr. Genet. 20:475-482, doi: 10.1007/BF00334775.

Die, J.V., B. Román, S. Nadal, and C.I. González-Verdejo. 2010. Evaluation of candidate reference genes for expression studies in Pisum sativum under different experimental conditions. Planta 232:145-153, doi: 10.1007/s00425-010-1158-1.

dos Santos, C.P., K.D. da Cruz Saraiva, M.C. Batista, T.A. Germano, and J.H. Costa. 2019. Identification and evaluation of reference genes for reliable normalization of real-time quantitative PCR data in acerola fruit, leaf, and flower. Mol. Biol. Rep. 47:1-13, doi: 10.1007/ s11033-019-05187-7.

Expósito-Rodríguez, M., A.A. Borges, A. Borges-Pérez, and J.A. Pérez. 2008. Selection of internal control genes for quantitative realtime RT-PCR studies during tomato development process. BMC Plant Biol. 8:131, doi: 10.1186/1471-2229-8-131.

Fernández Gómez, J. and Z.A. Wilson. 2014. A barley PHD finger transcription factor that confers male sterility by affecting tapetal development. Plant Biotechnol. J. 12:765-777, doi: 10.1111/pbi.12181.

Francis, J., G. Rea, N. Stephanie, N. Sheri, F. André, N.F. Hacker, H.S. Viola, and H. Sui. 2013. Careful selection of reference genes is required for reliable performance of RT-qPCR in human normal and cancer cell lines. PLoS One 8:e59180, doi: 10.1371/journal.pone.0059180.

Freeman, W.M., S.J. Walker, and K.E. Vrana. 1999. Quantitative RTPCR: Pitfalls and potential. Biotechniques 26:112-125, doi: 10.1002/ (SICI)1520-6343.

Fu, J., Y. Wang, H. Huang, C. Zhang, and S. Dai. 2013. Reference gene selection for RT-qPCR analysis of Chrysanthemum lavandulifolium during its flowering stages. Mol. Breed. 31:205-215, doi: 10.1007/s11032-012-9784-x.

Gómez, J.F., B. Talle, and Z.A. Wilson. 2015. Anther and pollen development: A conserved developmental pathway. J. Integr. Plant Biol. 57:876-891, doi: 10.1111/jipb.12425.

Goidin, D., A. Mamessier, M.J. Staquet, D. Schmitt, and O. BerthierVergnes. 2001. Ribosomal $18 S$ RNA prevails over glyceraldehyde-3phosphate dehydrogenase and beta-actin genes as internal standard for quantitative comparison of mRNA levels in invasive and noninvasive human melanoma cell subpopulations. Anal. Biochem. 295:17-21, doi: 10.1006/abio.2001.5171

Gu, C., S. Chen, Z. Liu, H. Shan, H. Luo, Z. Guan, and F. Chen. 2011. Reference gene selection for quantitative Real-Time PCR in chrysanthemum subjected to biotic and abiotic stress. Mol. Biotechnol. 49:192-197, doi: 10.1007/s12033-011-9394-6.

Gutierrez, L., M. Mauriat, S. Guénin, J. Pelloux, J.F. Lefebvre, R. Louvet, C. Rusterucci, T. Moritz, F. Guerineau, C. Bellini, and O. Van Wuytswinkel. 2008. The lack of a systematic validation of reference genes: A serious pitfall undervalued in reverse transcriptionpolymerase chain reaction (RT-PCR) analysis in plants. Plant Biotechnol. J. 6:609-618, doi: 10.1111/j.1467-7652.2008.00346.x.

Hu, R., C. Fan, H. Li, Q. Zhang, and Y.F. Fu. 2009. Evaluation of putative reference genes for gene expression normalization in soybean by quantitative real-time RT-PCR. BMC Mol. Biol. 10: doi: 10.1186/1471-2199-10-93.

Islam, M.T., A.S. Ferdous, S.S. Alam, and H. Khan. 2014. Selection and validation of reference gene(s) for gene expression analyses by quantitative PCR under different environmental stresses in jute. 7th Intl. Plant Tissue Culture Biotechnol. Conf., Dhaka, Bangladesh.

Jain, M., A. Nijhawan, A.K. Tyagi, and J.P. Khurana. 2006. Validation of housekeeping genes as internal control for studying gene expression in rice by quantitative real-time PCR. Biochem. Biophys. Res. Commun. 345:646-651, doi: 10.1016/j.bbrc.2006.04.140.

Jian, B., B. Liu, Y. Bi, W. Hou, C. Wu, and T. Han. 2008. Validation of internal control for gene expression study in soybean by quantitative real-time PCR. BMC Mol. Biol. 9:59, doi: 10.1186/1471-2199-9-59.

Kim, D.H., J.G. Kang, and B.D. Kim. 2007. Isolation and characterization of the cytoplasmic male sterility-associated orf456 gene of chili pepper (Capsicum annuum L.). Plant Mol. Biol. 63:519-532, doi: 10.1007/s11103-006-9106-y.

Kirthi, N., B. Roy-Chaudhuri, T. Kelley, and G.M. Culver. 2006. A novel single amino acid change in small subunit ribosomal protein S5 has profound effects on translational fidelity. RNA 12:2080-2091, doi: 10.1261/rna.302006.

Klumb, E.K., L.N. Rickes, E.J.B. Braga, and V.J. Bianchi. 2019. Evaluation of stability and validation of reference genes for real time PCR expression studies in leaves and roots of Prunus spp. rootstocks under flooding. Scientia Hort. 247:310-319, doi: 10.1016/j. scienta.2018.12.036.

Løvdal, T. and C. Lillo. 2009. Reference gene selection for quantitative real-time PCR normalization in tomato subjected to nitrogen, cold, and light stress. Anal. Biochem. 387:238-242, doi: 10.1016/j. ab.2009.01.024.

Li, Q.Q., J. Skinner, and J.E. Bennett. 2012. Evaluation of reference genes for real-time quantitative PCR studies in Candida glabrata following azole treatment. BMC Mol. Biol. 13:22, doi: 10.1186/ 1471-2199-13-22.

Li, Z.J., Y.F. Cheng, J.M. Cui, P.P. Zhang, H.X. Zhao, and S.W. Hu. 2015. Comparative transcriptome analysis reveals carbohydrate and lipid metabolism blocks in Brassica napus L. male sterility induced by the chemical hybridization agent monosulfuron ester sodium. BMC Genomics 16:206, doi: 10.1186/s12864-015-1388-5.

Lin, Y., A. Zhang, S. Yang, and L. Huang. 2019. Reference gene selection for real-time quantitative PCR normalization in Hemarthria compressa and Hemarthria altissima leaf tissue. Mol. Biol. Rep. 46:4763-4769, doi: 10.1007/s11033-019-04922-4.

Liu, Z., X.W. Cai, G.J. Seiler, C.C. Jan, and W. Friedt. 2015. Interspecific amphiploid - derived alloplasmic male sterility with defective anthers, narrow disc florets and small ray flowers in sunflower. Plant Breed. 133:742-747, doi: 10.1111/pbr.12216.

Luo, H.L., L.P. Luo, B.C. Guan, E.X. Li, D.J. Xiong, and B.T. Sun. 2014. Evaluation of candidate reference genes for RT-qPCR in lily (Lilium brownii). J. Hort. Sci. Biotechnol. 89:345-351.

Mafra, V., K.S. Kubo, M. Alves-Ferreira, M. Ribeiro-Alves, R.M. Stuart, L.P. Boava, C.M. Rodrigues, and M.A. Machado. 2012. Reference genes for accurate transcript normalization in citrus genotypes under different experimental conditions. PLoS One 7:e31263, doi: 10.1371/journal.pone.0031263.

Maria, C., P. Allison, A. Francesca, S. Pierluigi, V. Lorenza, and C.P. Maria. 2017. Systematic identification of human housekeeping genes possibly useful as references in gene expression studies. Mol. Med. Rep. 16:2397-2410, doi: 10.3892/mmr.2017.6944.

Mariot, R.F., L. Oliveira, M.M. Voorhuijzen, M. Staats, and J. Frazzon. 2015. Selection of reference genes for transcriptional analysis of edible tubers of potato (Solanum tuberosum L.). PLoS One 10:e0120854, doi: 10.1371/journal.pone.0120854.

Maroufi, A., E. Van Bockstaele, and M. De Loose. 2010. Validation of reference genes for gene expression analysis in chicory (Cichorium intybus) using quantitative real-time PCR. BMC Mol. Biol. 11:15, doi: 10.1186/1471-2199-11-15. 
Martins, P.K., V. Mafra, W.R.D. Souza, A.P. Ribeiro, F. Vinecky, M.F. Basso, B.A.D.B. da Cunha, A.K. Kobayashi, and H.B.C. Molinari. 2016. Selection of reliable reference genes for RT-qPCR analysis during developmental stages and abiotic stress in Setaria viridis. Sci. Rep. 6:28348, doi: 10.1038/srep28348.

Nicot, N., J.F. Hausman, L. Hoffmann, and D. Evers. 2005. Housekeeping gene selection for real-time RT-PCR normalization in potato during biotic and abiotic stress. J. Expt. Bot. 56:2907-2914, doi: 10.1093/jxb/eri285.

Pabinger, S., G.G. Thallinger, R. Snajder, H. Eichhorn, R. Rader, and Z. Trajanoski. 2009. QPCR: Application for real-time PCR data management and analysis. BMC Bioinformatics 10:268, doi: 10.1186/1471-2105-10-268.

Paolacci, A.R., O.A. Tanzarella, P. Enrico, and C. Mario. 2009. Identification and validation of reference genes for quantitative RT-PCR normalization in wheat. BMC Mol. Biol. 10:11, doi: 10.1186/1471-2199-10-11.

Park, S.C., Y.H. Kim, C. Ji, S. Park, J.C. Jeong, H.S. Lee, and S.S. Kwak. 2012. Stable internal reference genes for the normalization of real-time PCR in different sweetpotato cultivars subjected to abiotic stress conditions. PLoS One 7:e51502, doi: 10.1371/journal.pone.0051502.

Perini, P., P. Giancarlo, M. Margis-Pinheiro, P.R.D. de Oliviera, and L.F. Revers. 2014. Reference genes for transcriptional analysis of flowering and fruit ripening stages in apple (Malus $\times$ domestica Borkh.). Mol. Breed. 34:829-842, doi: 10.1007/s11032-014-0078-3.

Pfaffl, M.W., A. Tichopad, C. Prgomet, and T.P. Neuvians. 2004. Determination of stable housekeeping genes, differentially regulated target genes and sample integrity: BestKeeper-Excel-Based tool using pair-wise correlations. Biotechnol. Lett. 26:509-515, doi: 10.1023/B:BILE.0000019559.84305.47.

Piehler, A.P., R.M. Grimholt, R. Øvstebø, and J.P. Berg. 2010. Gene expression results in lipopolysaccharide-stimulated monocytes depend significantly on the choice of reference genes. BMC Immunol. 11:21, doi: 10.1186/1471-2172-11-21.

Pring, D.R., H.V. Tang, C.D. Chase, and M.N. Siripant. 2006. Microspore gene expression associated with cytoplasmic male sterility and fertility restoration in sorghum. Sex. Plant Reprod. 19:25-35, doi: 10.1007/s00497-005-0019-8.

Qi, S., L. Yang, X. Wen, Y. Hong, X. Song, M. Zhang, and S. Dai. 2016. Reference gene selection for RT-qPCR analysis of flower development in Chrysanthemum morifolium and Chrysanthemum lavandulifolium. Front. Plant Sci. 7:287, doi: 10.3389/fpls.2016.00287.

Radoni, A., S. Thulke, I.M. Mackay, O. Landt, W. Siegert, and A. Nitsche. 2004. Guideline to reference gene selection for quantitative real-time PCR. Biochem. Biophys. Res. Commun. 313:856-862, doi: 10.1016/j.bbrc.2003.11.177.

Raman, B., M. Priyanka, B.J. Cassone, M. Praveen, M.G. Redinbaugh, M. Andy, and A. Sara. 2015. Recommended reference genes for quantitative PCR analysis in soybean have variable stabilities during diverse biotic stresses. PLoS One 10:e0134890, doi: 10.1371/journal. pone. 0134890 .

Schmidt, G.W. and S.K. Delaney. 2010. Stable internal reference genes for normalization of real-time RT-PCR in tobacco (Nicotiana tabacum) during development and abiotic stress. Mol. Genet. Genomics 283:233-241, doi: 10.1007/s00438-010-0511-1.

Scholtz, J.J. and B. Visser. 2013. Reference gene selection for qPCR gene expression analysis of rust-infected wheat. Physiol. Mol. Plant Pathol. 81:22, doi: 10.1016/j.pmpp.2012.10.006.

Sestili, S., M.S. Sebastiani, A. Belisario, and N. Ficcadenti. 2014. Reference gene selection for gene expression analysis in melon infected by Fusarium oxysporum f.sp. melonis. Indian J. Malariol. 23:154-158, doi: 10.1007/s13562-013-0207-9.

Sreekala, C. and S.P.S. Raghava. 2003. Exploitation of heterosis for carotenoid content in African marigold (Tagetes erecta L.) and its correlation with esterase polymorphism. Theor. Appl. Genet. 106:771-776, doi: 10.1007/s00122-002-1143-6.
Sturzenbaum, S.R. and P. Kille. 2001. Control genes in quantitative molecular biological techniques: The variability of invariance. Comp. Biochem. Physiol. B Biochem. Mol. Biol. 130:281-289, doi: 10.1016/ S1096-4959(01)00440-7.

Tang, N., W. Liu, W. Zhang, and D. Tang. 2020. Integrative analysis of transcriptomic and proteomic changes related to male sterility in Tagetes erecta. Physiol. Mol. Biol. Plants 26:2061-2074, doi: 10.1007/ s12298-020-00886-z.

Thellin, O., W. Zorzi, B. Lakaye, B. De Borman, B. Coumans, G. Hennen, T. Grisar, A. Igout, and E. Heinen. 1999. Housekeeping genes as internal standards: Use and limits. J. Biotechnol. 75:291-295, doi: 10.1016/S0168-1656(99)00163-7.

Thorrez, L., K. Van Deun, L.C. Tranchevent, L. Van Lommel, K. Engelen, K. Marchal, Y. Moreau, I. Van Mechelen, and F. Schuit. 2008. Using ribosomal protein genes as reference: A tale of caution. PLoS One 3:e1854, doi: 10.1371/journal.pone.0001854.

Tian, C., Q. Jiang, F. Wang, G.L. Wang, Z.S. Xu, and A.S. Xiong. 2015. Selection of suitable reference genes for qPCR normalization under abiotic stresses and hormone stimuli in carrot leaves. PLoS One 10:e0117569, doi: 10.1371/journal.pone.0117569.

Tomasz, C., M. Stitt, T. Altmann, M.K. Udvardi, and W.-R. Scheible. 2005. Genome-wide identification and testing of superior reference genes for transcript normalization in arabidopsis. Plant Physiol. 139:5-17, doi: 10.1104/pp.105.063743.

Tong, Z., Z. Gao, F. Wang, J. Zhou, and Z. Zhang. 2009. Selection of reliable reference genes for gene expression studies in peach using real-time PCR. BMC Mol. Biol. 10:71, doi: 10.1186/1471-2199-10-71.

Vandesompele, J., K. De Preter, F. Pattyn, B. Poppe, N. Van Roy, A. De Paepe, and F. Speleman. 2002. Accurate normalization of real-time quantitative RT-PCR data by geometric averaging of multiple internal control genes. Genome Biol. 3:research0034.0031, doi: 10.1186/gb-2002-3-7-research0034.

Villar-Martínez, A.A.D., P.A. García-Saucedo, A. Carabez-Trejo, A. Cruz-Hernández, and O. Paredes-López. 2005. Carotenogenic gene expression and ultrastructural changes during development in marigold. J. Plant Physiol. 162:1046-1056, doi: 10.1016/j.jplph.2004.12.004.

Wang, H., J. Wang, J. Jiang, S. Chen, Z. Guan, Y. Liao, and F. Chen. 2014a. Reference genes for normalizing transcription in diploid and tetraploid arabidopsis. Sci. Rep. 4:6781, doi: 10.1038/srep06781.

Wang, T., R. Hao, H. Pan, T. Cheng, and Q. Zhang. 2014b. Selection of suitable reference genes for quantitative Real-time polymerase chain reaction in Prunus mume during flowering stages and under different abiotic stress conditions. J. Amer. Soc. Hort. Sci. 139:113-122, doi: 10.1051/fruits/2014004.

Xiang, Q., J. Li, P. Qin, M. He, X. Yu, K. Zhao, X. Zhang, M. Ma, Q. Chen, and X. Chen. 2018. Identification and evaluation of reference genes for qRT-PCR studies in Lentinula edodes. PLoS One 13:e0190226, doi: 10.1371/journal.pone.0190226.

Xiao, Z., X. Sun, X. Liu, C. Li, L. He, S. Chen, and J. Su. 2016. Selection of reliable reference genes for gene expression studies on Rhododendron molle G. Don. Front. Plant Sci. 7:1547, doi: 10.3389/ fpls.2016.01547.

Xie, F., P. Xiao, D. Chen, L. Xu, and B. Zhang. 2012. miRDeepFinder: A miRNA analysis tool for deep sequencing of plant small RNAs. Plant Mol. Biol. 80:75-84, doi: 10.1007/s11103-012-9885-2.

Xu, J., Z. Ding, G. Vizcay-Barrena, J. Shi, W. Liang, Z. Yuan, D. Werck-Reichhart, L. Schreiber, Z.A. Wilson, and D. Zhang. 2014. ABORTED MICROSPORES acts as a master regulator of pollen wall formation in Arabidopsis. The Plant Cell 26:1544-1556, doi: 10.1105/ tpc.114.122986.

Xu, M., B. Zhang, X. Su, S. Zhang, and M. Huang. 2011. Reference gene selection for quantitative real-time polymerase chain reaction in Populus. Anal. Biochem. 408:337-339, doi: 10.1016/j.ab.2010.08.044.

Yan, L., J. Su, Z. Wang, X. Yan, and R. Yu. 2017. Selection of reference genes for expression analysis of Kumamoto and Portuguese oysters and their hybrid. J. Ocean Univ. China 16:1139-1147, doi: 10.1007/s11802-017-3339-z. 
Yang, J., T. Wang, Y.L. Zhu, C.F. Hu, K. Wang, X.J. Peng, J.P. Tong, S.Q. Li, and Y.G. Zhu. 2010. The mitochondrial gene orfH79 plays a critical role in impairing both male gametophyte development and root growth in CMS-Honglian rice. BMC Plant Biol. 10:125, doi: 10.1186/1471-2229-10-125.

Yi, S., Y. Qian, L. Han, Z. Sun, C. Fan, J. Liu, and G. Ju. 2004. Selection of reliable reference genes for gene expression studies in Rhododendron micranthum Turcz. Scientia Hort. 99:128-133, doi: 10.1016/j.scienta.2012.02.013.

Zhou, L., Q.E. Lim, G. Wan, and H.P. Too. 2010. Normalization with genes encoding ribosomal proteins but not GAPDH provides an accurate quantification of gene expressions in neuronal differentiation of PC12 cells. BMC Genomics 11:75, doi: 10.1186/1471-2164-11-75. Zhu, L., C. Yang, Y. You, W. Liang, N. Wang, F. Ma, and C. Li. 2019. Validation of reference genes for qRT-PCR analysis in peel and flesh of six apple cultivars (Malus domestica) at diverse stages of fruit development. Scientia Hort. 244:165-171, doi: 10.1016/j. scienta.2018.09.033.

Zhu, X., X. Li, W. Chen, J. Chen, W. Lu, L. Chen, and D. Fu. 2012. Evaluation of new reference genes in papaya for accurate transcript normalization under different experimental conditions. PLoS One 7:e44405, doi: 10.1371/journal.pone.0044405. 


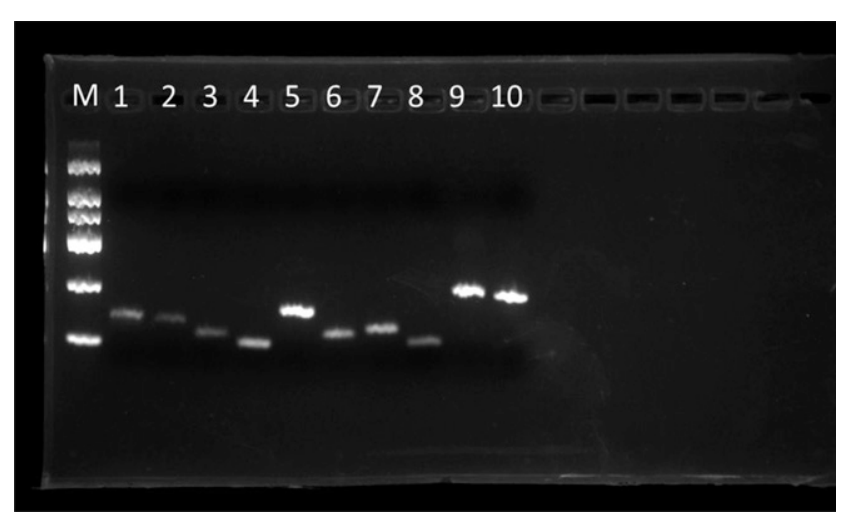

Supplemental Fig. 1. Agarose gel electrophoresis for the 10 candidate reference genes in flower buds of marigold; 1 through 10 represent reference genes $E F 1$, RPS5, RPS24, EF2, $18 S, U B C, T U B, A C T B, G A P D H$, and $P A L$, respectively.

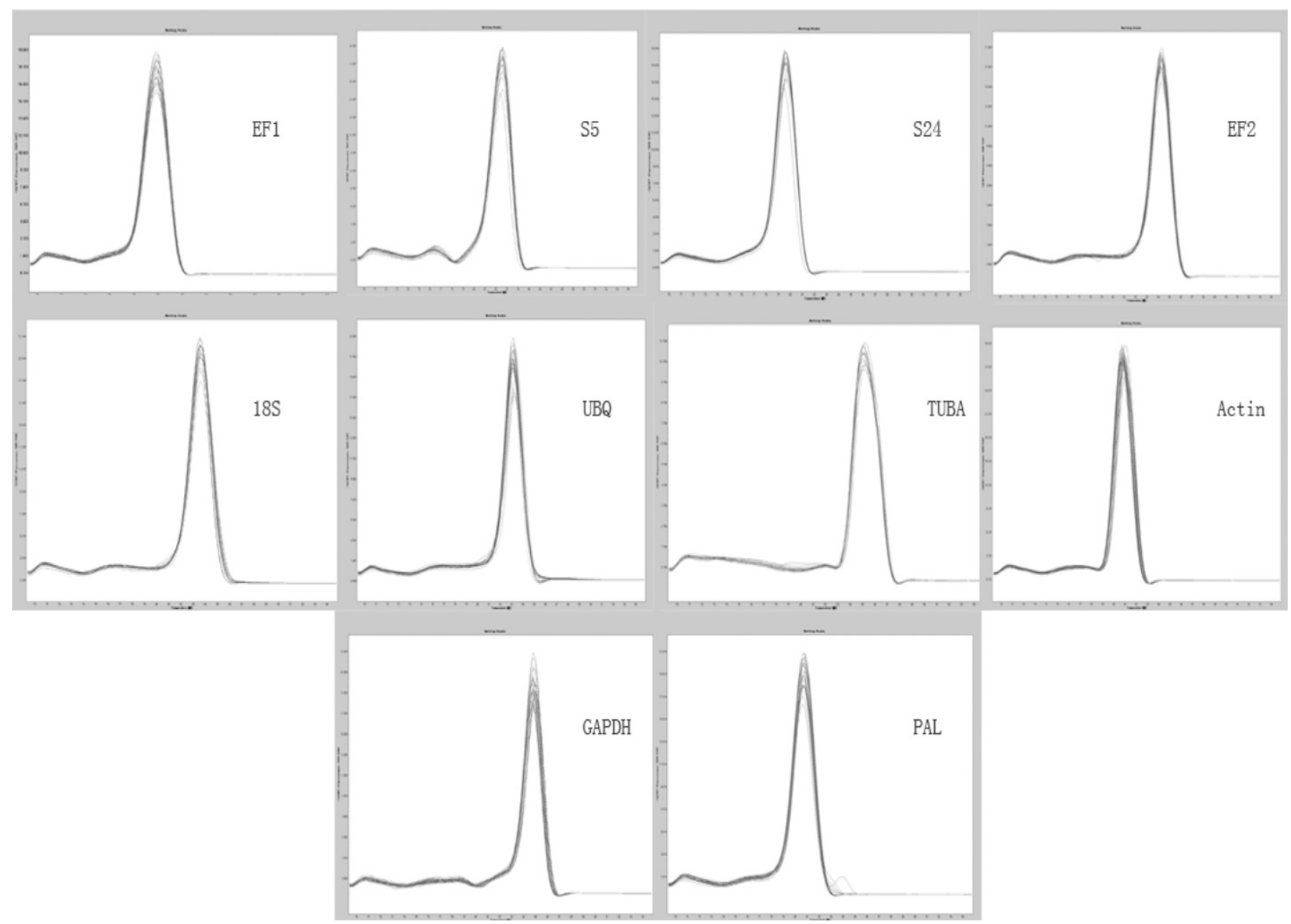

Supplemental Fig. 2. Melting curve of the 10 candidate reference gene in flower buds of marigold. 
Supplemental Table 1. Ranking of 10 reference genes in flower buds of marigold and their expression stability (M) values calculated by geNorm (Vandesompele et al., 2002).

\begin{tabular}{|c|c|c|c|c|}
\hline \multirow[b]{2}{*}{ Ranking $^{\mathrm{z}}$} & \multicolumn{2}{|c|}{ Male-sterile } & \multicolumn{2}{|c|}{ Male-fertile } \\
\hline & Gene & M & Gene & M \\
\hline 1 & RPS5 & 1.052 & $E F 1 \alpha$ & 0.719 \\
\hline 2 & $18 S$ & 1.079 & RPS5 & 0.736 \\
\hline 3 & GAPDH & 1.091 & $G A P D H$ & 0.755 \\
\hline 4 & $R P S 24$ & 1.142 & $R P S 24$ & 0.791 \\
\hline 5 & $U B C$ & 1.144 & $U B C$ & 0.792 \\
\hline 6 & $P A L$ & 1.166 & $E F 2$ & 0.902 \\
\hline 7 & $E F 1 \alpha$ & 1.319 & $18 S$ & 1.003 \\
\hline 8 & $E F 2$ & 1.336 & $A C T B$ & 1.135 \\
\hline 9 & $T U B$ & 1.471 & $T U B$ & 1.224 \\
\hline 10 & $A C T B$ & 1.495 & $P A L$ & 2.280 \\
\hline
\end{tabular}

